\title{
Industrial Production and Monetary Shocks: Empirical Evidence from Pakistan
}

\author{
Sadaf Shahab $^{\text {a }}$, Muhammad Tariq Mahmood ${ }^{\text {b }}$, Azmat Fatima ${ }^{\mathrm{c}}$ \\ ${ }^{a}$ Assistant Professor, Department Of Economics, Federal Urdu University, Islamabad, Pakistan \\ Email: shahab.sadaf@gmail.com \\ Assistant Professor and Head, Department Of Commerce, Federal Urdu University, Islamabad, Pakistan \\ Email:tm76pk@gmail.com \\ M. Phil Scholar, Department Of Economics, Federal Urdu University, Islamabad, Pakistan \\ Email: azmatfatima1o@yahoo.com
}

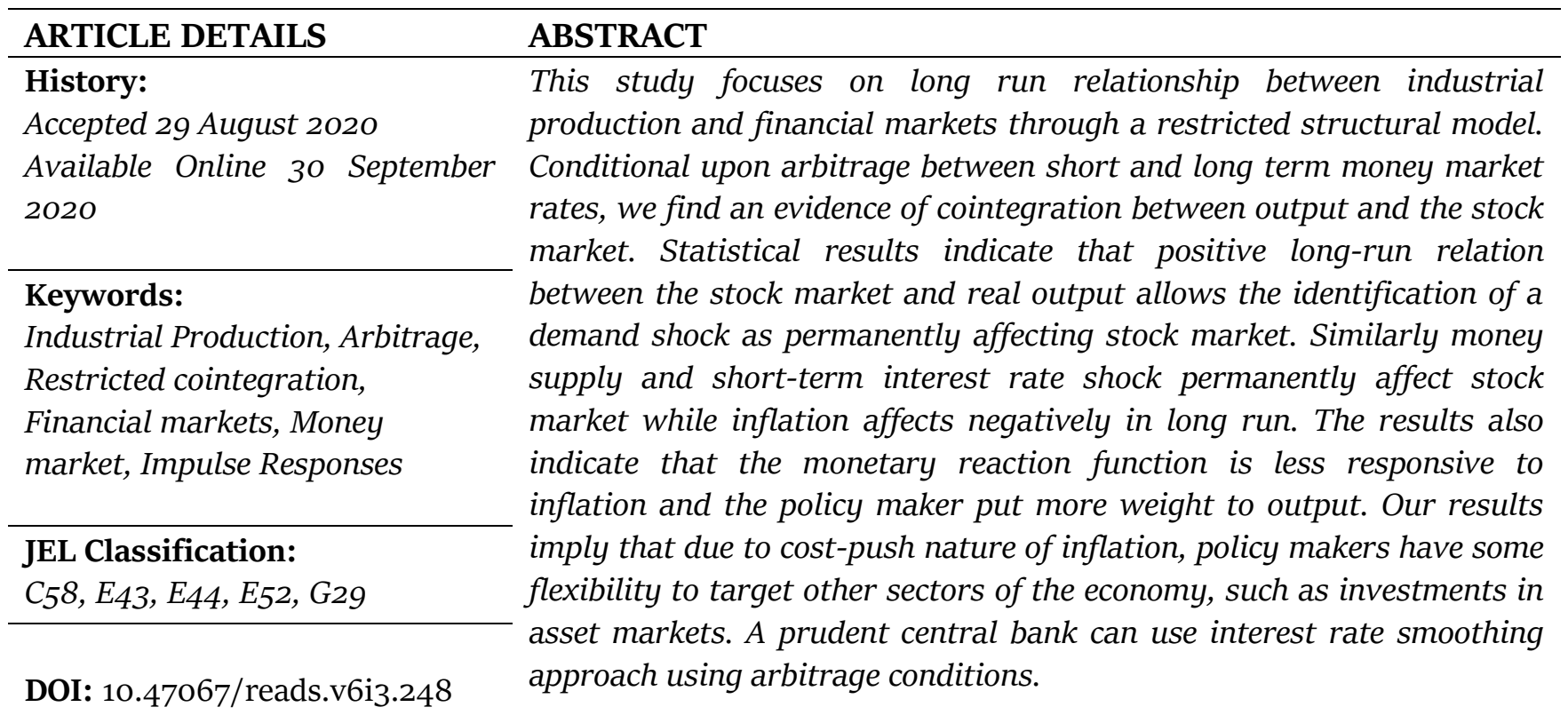

(C) 2020 The authors. Published by SPCRD Global Publishing. This is an open access article under the Creative Commons Attribution-

NonCommercial 4.0

Corresponding author's email address: shahab.sadaf@gmail.com

\section{Introduction}

The Industrial production and its impact on the economies has been an interest of academic literature for centuries now.1 However, the idea of its link to financial innovation of a country has emerged more recently. During 1990's a number of econometric instruments were employed to investigate the possibly ambiguous association between financial activities and economic growth.

Many analyses of financial sector segregated all financial markets into two categories: the market for money and the market for everything else. With reference to its structure, the symmetry in revolution.

1 In his poem The Fable of the Bees Bernard Mandeville (1670-1733) took an early account of industrial 


\section{Review of Economics and Development Studies, Vol. 6 (3) 2020, 575-589}

information is vital to increase participants' confidence and efficiency of a financial market. However, the only real force that ultimately makes a financial market (for example stock market) rise or fall over the long run is simply changes in money resulting an increase in stocks due to monetary inflation. In short, the key link between financial market and output is primarily driven by money or credit. Thus, such a hypotheses needs to be studied broadly.

In a business cycle context, during expansion, economy of scale holds which increases real wealth, offsetting the effect of nominal money. However, if the production of goods is faster than the growth of money, prices decline. On the other hand, if prices rise because of increase in money supply faster than goods, yet the prices fall in real terms, because the wages increase faster than prices. Hence, if there were constant amount of money in economy, it is harder to increase sum of all shares of all stock taken together. Correspondingly, if firms' profit, on an aggregate level does not increase, there would not be any addition in per share earnings accredited into prices of the stocks. Nevertheless, it may move slightly lower depending upon rate of change of issued shares. This situation would generate recession in the economy: the aggregate economic activity will show downturn. As a consequence, the price of leading firms' stocks increase leaving others to lose (Gauthier \& Liu, 2003).

The prime objective of this study is to find out the linkage between real economy and stock market for an emerging economy. We employ King et.al. (1987) and Gauthier \& Li (2005) approach in a modified way and empirically test for Pakistan. Thus specifically this study aims at; firstly, to analyze the modeled linkage between real economy and stock market; secondly, to empirically investigate the arbitrage between short- and long-term money market equilibrium; and thirdly, to find out relative response among variables of the model in a vector autoregressive process.

The study is organized as follows: after this brief introduction, section two reviews the existing literature, section three is based on model and methodology of the study, section four analyses the empirical results, and section five concludes.

\section{Literature Review}

To foresee turning points in aggregate economic activity, there are two potential implications that can elaborate the role of financial variables. First, tighter financial and credit position limits potential for firm's decisions to expand and borrow. Second, asset prices are determined in a forward looking market and rely on anticipated profitability of firms (Espinoza, Fornari, \& Lombardi, 2012).

Gauthier \& Liu (2003) took a detailed account of the financial conditions index (FCI) through different methodological options and show that equity prices, short and long term yield rates, bond risk premier and exchange rates do significantly affect output. For such effect first differenced data are generally used as useful tool for both policy makers and financial market participants. However, possible asymmetries are observed for euro area (Angelopoulou, Balfoussia, \& Gibson, 2014). Prices play a significant and decisive role to utilize information by economic agents to monitor the market, being an aggregate piece of information and eventually imitate a precise estimate of firm's value. The real decision makers; financial capital providers, regulators, managers, employees and customers learn from to practicing it to direct their decisions (Baumol, 1965).

The excessive money supply by central bank to run the country involves a higher inflation if indicators such as interest rate, consumer prices are not controlled within the given limits. Among others, (Eichenbaum, 1997) confirms a stable long run relationship among output, prices and money supply and this stability supports an economic agent in decision making. In short run monetary stance 


\section{Review of Economics and Development Studies, Vol. 6 (3) 2020, 575-589}

is more operative relatively by causing some significant movement in price level. An upsurge in liquidity may raise economic activity, which sequentially increases demand for money (Soejima, 1996).

In long-run, inflation has negative effect on stock prices whereas industrial production index (IPI), liquidity and real affective exchange rate (REER) affect positively on stock returns (see for example Sohail \& Zakir, 2009 for Pakistan) and correct monetary measures are necessarily to be adopted by monetary authorities to curb and control inflation to minimize the volatility of the stock markets, little but enduring inflation is "lubing the wheels of trade."

The structuralism contend that inflation is pivotal for lubing the wheels of the economy while the monetarists place that expansion is destructive to financial growth (Doguwa, 2012). Some studies affirm that low and stable expansion advances monetary development and the other way around (Mubarik, 2005; Ahmed and Mortaza, 2005). Blanchard and Quah (1989) found that inflation does not affect real yield over the long run but rather in the short.

The empirical findings like Herando and Martínez-Carrascal (2008) reveal that financial position is significant to explain corporate decisions on fixed investment and employment and the influence is more powerful when financial pressure outstrips a certain threshold. The extrapolative capability of financial variables for euro area growth reveal that financial variables are prominent indicators for euro zone growth at a collective level, although at diverse horizons during one to six quarters (Guichard, et al., 2009). However, in mid of 1980, financial innovation influenced consumer spending, housing investment and business fixed investment in many of the OECD economies (Dynan et al., 2006).

Ahmed and Mortaza (2005) propose an optimum level of inflation above which, expansion is negative for financial development and found the existence of critical long term negative relationship. Ayyoub, et.al. (2011) noted negative relationship between economic development and inflation. Chaudhry, et. al., (2012) explore the long and short run connections of fiscal arrangement, inflation and financial development, showing that private credit and shortfall of spending plan are discovered as flexible and critical variables to impact real output.

To inquire the direction and nature of the relationship between economic growth and stock market volatility, it is argued that development of the financial sector stimulates economic activity and for this reason increases economic growth in the longer span of time (Puah and Jayaraman, 2007) and there is a significant impact of these variables in long run (Liu and Shrestha, 2008). For countries like BRICS no statistically significant relationship is observed among stock indices, exchange rate and other variables as used by Adam and George (2008). Their results confirm positive and significant relation between GDP, stocks and the consumption. Earlier, Fama (1981) found that there has been a strong relationship between stock prices and gross domestic product. Similalry, Humpe and Macmillan (2009) discover positive and significant long-run relationship between US stock prices and industrial production. On the other hand, Comincioli and Wesleyan (1996) show that stock market is helpless for forecasting the economy. In the recent literature, some studies reported positive effect of interest rate on stock returns whereas; some studies pointed negative. For example, Ratanapakorn, \& Sharma (2007) report positive relationship and Humpe and Macmillan, (2009) showed negative effect of T-bill rate.

So, this review suggests that there exists a long run cointegration between the output, money, stock market, inflation and interest rate. Likewise financial sector development stimulates economics activity in both long and short run; and that shocks in stock market do help in predicting the economic fluctuations. However, the lack of consensus is observed on the role of interest rate and ambiguity holds 


\section{Review of Economics and Development Studies, Vol. 6 (3) 2020, 575-589}

in general. So, in this study we look issue of financial market and the monetary response function in the presence of arbitrage under restrictions imposed by macroeconomic conditions.

\section{Model and Methodology}

In this part, long run relations are described as the building block of our model which is based on Blanchard (1981) and Gauthier and Li (2005), who developed the model to link between the real economic activity and stock market, using the arbitrage between short \& long term bonds. The base of the model is formed by the relationship in the output and the financial markets, and then moved towards the money market equilibrium and arbitrage between short \& long run bonds than finally the reduced-form solution is drawn.

From a perspective of asset prices transmissions, through the channel of wealth effects, as money supply increases, the stock price increase indicates a hike in financial wealth; the consumption should eventually increase causing output to expand. A rise in real income (per capita) provides them greater financial resources for spending or saving at a rate of respective marginal propensities.

\subsection{Linkages between Real Economy and Asset Market}

The traditional theories forward two main determinants of consumption/spending: (i) current disposable income; and (ii) value of shares in a stock market. The effect of later may be direct through the wealth effect on consumers, or indirect through the "borrowing capacity of consumers and investors" (the credit channel effect).

Consumption spending is expressed as:
$C S_{t}=\alpha_{1} s m_{t}+\alpha_{2} y_{t}$
$\alpha_{1}>0 ; \alpha_{2}>0$

Where $\boldsymbol{C S}$ denotes consumption, sm denotes stock market, and $\boldsymbol{y}$ is income; and all variables are real. Equation (1) is forward looking aggregate consumption spending where $\boldsymbol{s m}$ represents a function that comprises the present value of expected future profits and $\boldsymbol{y}$ showing function of expected future output. Output adjusts to consumption overtime. Putting value of CS in above equation we get,

$$
\begin{gathered}
y_{t}^{\cdot}=\sigma\left(\alpha_{1} s m_{t}+\alpha_{2} y_{t}-y_{t}\right) \\
y_{t}^{\cdot}=\sigma\left(\alpha_{1} s m_{t}-\left(1-\alpha_{2}\right) y_{t}\right)
\end{gathered}
$$

We put $\beta=\left(1-\alpha_{2}\right)$, and get;

$$
y_{t}^{\cdot}=\sigma\left(\alpha_{1} s m_{t}-\beta y_{t}\right) \quad \text { (2) } \quad \sigma>0
$$

Where dot $\left({ }^{*}\right)$ symbolizes a time derivative. Equation (2) can be considered as error correction procedure linking the short-run dynamics of output positively to deviations of the stock market from real economy.

\subsection{Money market equilibrium}

It is based on demand and supply forces for money as:

Where, $\mathrm{MS}=\mathrm{M} / \mathrm{P}$, and

$$
M S=M D
$$

$$
M D=L(Y, i) \text { or } M D=L\left(Y, r+\pi^{e}\right)
$$


However, we can assume $\pi=\pi^{\mathrm{e}}$ because we are assuming static inflation, and Equating MD and MS we get

$$
\frac{M}{P}=L(Y, r+\pi)
$$

Where $\mathrm{M}$ stands for nominal money, $\mathrm{P}$ for prices, $\mathrm{Y}, \mathrm{r}, \pi$ denote output, real interest rate and inflation respectively. Taking logs;

By solving, we get

$$
\ln \left(\frac{M}{P}\right)=\ln [L(Y, r+\pi)]
$$

$$
\begin{aligned}
m-p=\alpha_{1} Y_{t}+\alpha_{2}\left(r+\pi_{t}\right) \\
m=\alpha_{1} Y_{t}+\alpha_{2} i_{t}+\alpha_{3} \pi_{t}
\end{aligned}
$$

$$
\alpha_{1}>0, \alpha_{2}<0, \alpha_{3}<0
$$

Where, we have used inflation as proxy for log of prices. In long-run Portfolio balance is characterized by relation between money, output, interest rate and inflation.

\subsection{Arbitrage between short- and long-term financial asset}

The most instinctive theory about term structure of returns is the expectations hypothesis. If $\boldsymbol{l} \boldsymbol{r}_{\boldsymbol{t}}$ is the nominal yield to maturity of a discount bond and $i_{t}$ is one-period rate, expectations hypothesis in nonexistence of uncertainty implies that,

$$
\left(1+I r_{t}\right)^{n}=\sum_{i=0}^{n-1}\left(1+i_{t+1}\right)
$$

This is an "arbitrage condition" ensuring that the yield of holding-period for an n-period bond is equivalent to a yield of holding a chain of one-period bonds. Applying logs and considering that $\ln (1+$ $x) \sim x$ for small $x$, yields a familiar approximation:

$$
\begin{aligned}
& n \cdot \ln \left(1+I_{r t}\right)=\sum_{i=0}^{n-1} 1+i_{t+1} \\
& I r_{t}=\frac{1}{n} \sum_{i=0}^{n-1}+i_{t+1}
\end{aligned}
$$

The long-term yield equals an average of single-period yields. Hence, a permanent shock to a shortterm yield will be reflected one for one in the long-term yield, until the shock is suitably perceived to be permanent by markets.

\subsection{Core Model}

The three main long-run equilibria can be written as:

$$
\begin{gathered}
m_{t}=\alpha_{11}+\alpha_{12} Y_{t}+\alpha_{13} i_{t}+\alpha_{14} \pi_{t}+\mu_{1 t} \\
s m_{t}=\alpha_{31}-Y_{t}+\mu_{3 t}
\end{gathered}
$$




$$
I r_{t}=\alpha_{21}-i_{t}+\mu_{2 t}
$$

The three long run equation can be written as,

$$
\mu_{t}=\beta \mathrm{Z}_{t-1}-c_{\circ}
$$

Where $\mathrm{z}_{\mathrm{t}}=\left(\pi_{\mathrm{t}}, \mathrm{Y}_{\mathrm{t}}, \mathrm{it}, \mathrm{m}_{\mathrm{t}}, \mathrm{sm}_{\mathrm{t}}, \mathrm{Ir}_{\mathrm{t}}\right)$. Equation 9 can be written a

$$
\left[\begin{array}{cccccc}
-\alpha_{14} & -\alpha_{12} & -\alpha_{13} & 1 & -\alpha_{15} & -\alpha_{17} \\
-\alpha_{24} & -\alpha_{22} & -\alpha_{23}-\alpha_{26} & -\alpha_{25} & 1 \\
-\alpha_{34} & -\alpha_{32} & -\alpha_{33}-\alpha_{36} & 1 & -\alpha_{37}
\end{array}\right]\left[\begin{array}{c}
\pi_{t-1} \\
Y_{t-1} \\
i_{t-1} \\
m_{t-1} \\
s m_{t-1} \\
I r_{t-1}
\end{array}\right]-\left[\begin{array}{l}
a_{11} \\
a_{21} \\
a_{31}
\end{array}\right]=\left[\begin{array}{l}
\mu_{1 t} \\
\mu_{1 t} \\
\mu_{1 t}
\end{array}\right] \text { (10) }
$$

After applying the restriction, it become

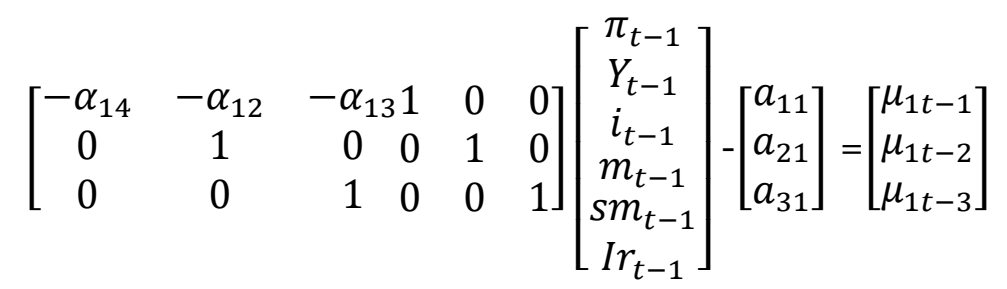

Equation 11 is the reduced form of core model with all six variables, form a restricted VAR. In this equation as compared to equation $9, \beta$ is vector of error correction coefficients, $z$ is vector representing the six endogenous variables, $\mathrm{C}_{\mathrm{o}}$ is a vector of fixed intercepts and $\mu_{t}$ is a definite matrix. Those variables which have time variant relationship in a vector autoregressive (VAR) process are to be expected to have some degree of contemporaneous connection. We here presume that the model is with a set of identifying restrictions because the identification of structured shocks is somehow required in a surge to estimate the effect of an endogenous variable on dynamic pathways of all variables of system which we call impulse response function (Lin 2006).

\subsection{Data and Estimation Techniques}

For this empirical model, output is characterized by industries production index; while stock exchange volume is used to proximate financial market. The market equilibrium is investigated by computing equilibrium in monetary markets that is between supply and demand of money. Inflation, interest rate and output are attributed to calculate money demand in the market. The said analysis has been made on quarterly data ranging from 1991Q:3 - 2015Q:2. The data are taken from different sources; IMF (IFS), PSE, and SBP and is manipulated according to the requirement of the study. For example; in a quarterly time series, the seasonal adjustment process is based on the removal of the seasonal movements from a data series and extracting relevant/underlying trend component. So, one of main tasks we faced is to solve the problem of seasonality in a time series. 
Review of Economics and Development Studies, Vol. 6 (3) 2020, 575-589

Table 1: Variables Description

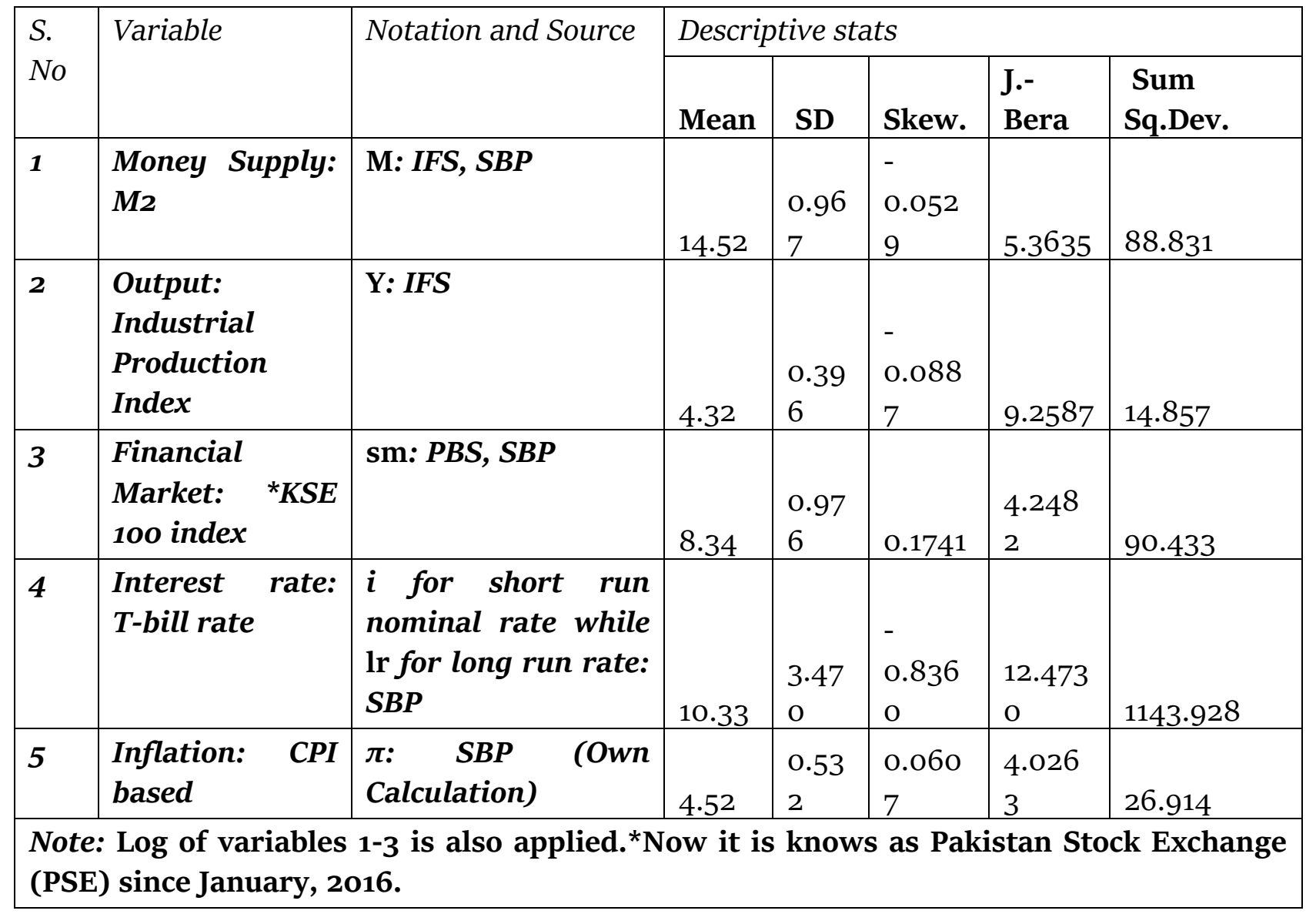

\section{Results and Discussion}

To analyze the model discussed above we first test the series for stationarity and found that three main stock variables of the model are integrated of order 1 (Table 2) and exhibit a unit root. Thus it is worthy to conclude that there are chances of cointegration between money supply, industrial production and stock market volume. However, the unit root test indicates the interest rate series is to be stationary at level, but as we are using arbitrage condition, the interest rate is converted into a long run rate, thus it is presumed to be cointegrated with the other variables of the model. Secondly we employ King et al. (1987) and Gauthier and Li (2005) approach in our methodological framework to allowing an identification of permanent shocks the system. Thus the VEC restrictions according to equation 11 are applied to confirm the long run stability among the variables.

TABLE 2: SUMMERY OF UNIT ROOT TEST OF ALL SERIES

\begin{tabular}{|c|c|l|l|l|l|}
\hline Serie & Coefficients & $\begin{array}{l}\text { Trend/ } \\
\text { Intercept }\end{array}$ & $\begin{array}{l}\text { ADF } \\
\text { Stat }\end{array}$ & $\begin{array}{l}\text { Critical } \\
\text { Value }\end{array}$ & $\begin{array}{l}\text { Order } \\
\text { Integration }\end{array}$ \\
\hline $\mathbf{M 2}$ & -0.51 & None & -5.61 & -1.94 & 1st Difference \\
\hline $\mathbf{Y}$ & -0.46 & Both & -5.3 & -3.45 & 1st Difference \\
\hline $\mathbf{S m}$ & -1.55 & None & -5.1 & -3.45 & 1st Difference \\
\hline $\boldsymbol{i}$ & -0.25 & Intercept & -3.61 & -2.89 & Level \\
\hline $\boldsymbol{\Pi}$ & -0.26 & Intercept & -3.69 & -2.89 & Level \\
\hline
\end{tabular}




\subsection{The Long run Analysis}

On the basis of the above mentioned theoretical foundation, it is expected to find three cointegrating relations in the vector error correction model. The Model (results in Table 3) shows that trace test indicate three co-integrating equations at 5\% level of significance and Max-Eigen value test indicate the presence of two co-integrating equations at the same $5 \%$ level of significance.

To distinguish between the two co-integration tests, the t-values of $\boldsymbol{\alpha}$ coefficients (of eq. 11) are looked through, as recommended by Hendry and Juselius (2001); when these are very small, (if e.g., less than 3), then one would not lose greatly by excluding that vector as a co-integration relation in the model. As the t-values are significant for more than three (see table 4 below) for all the vectors and theoretical foundations also suggest the existence of three co-integrating vectors so we move forward with the assumption that model has three vectors. As the cointegration test indicates the existence of cointegration we have applied cointegration on restricted core model to identify the validity of our assumptions.

TABLE 3: Co-INTEgRATION TESTS

\begin{tabular}{|c|c|c|c|c|}
\hline $\begin{array}{c}\text { Max-Eigen } \\
\text { Statistics }\end{array}$ & $\begin{array}{c}\text { Trace } \\
\text { Statistics }\end{array}$ & $\begin{array}{l}\text { Null } \\
\text { Hypothesis } \\
\text { r=0 }\end{array}$ & $\begin{array}{c}\text { Max-Eigen } \\
\text { o.05 } \\
\text { (With prob) }\end{array}$ & $\begin{array}{l}\text { Trace 0.05 } \\
\text { (With prob) }\end{array}$ \\
\hline $\mathbf{7 5 . 7 9}$ & 160.29 & 0 & $\begin{array}{l}36.63 \\
(0.00)\end{array}$ & $\begin{array}{l}83.84 \\
(0.00)\end{array}$ \\
\hline $\mathbf{4 2 . 0 7}$ & 84.50 & 1 & $\begin{array}{l}30.44 \\
(0.001)\end{array}$ & $\begin{array}{l}60.06 \\
(0.00)\end{array}$ \\
\hline $\mathbf{2 0 . 5 1}$ & 42.43 & 2 & $\begin{array}{l}24.16 \\
(0.145)\end{array}$ & $\begin{array}{l}40.17 \\
(0.029)\end{array}$ \\
\hline $\mathbf{1 1 . 3 9}$ & 21.91 & 3 & $\begin{array}{l}17.79 \\
(0.35)\end{array}$ & $\begin{array}{l}24.27 \\
(0.096)\end{array}$ \\
\hline $\mathbf{6 . 6 2}$ & 10.52 & 4 & $\begin{array}{l}11.22 \\
(0.28)\end{array}$ & $\begin{array}{l}12.32 \\
(0.098)\end{array}$ \\
\hline $\mathbf{3 . 9 0}$ & 3.91 & 5 & $\begin{array}{l}4.12 \\
(0.057)\end{array}$ & $\begin{array}{l}4.13 \\
(0.572)\end{array}$ \\
\hline
\end{tabular}

TABLE 4: RESTRICTIONS TEST ON CO-INTEGRATING VECTORS

The LR test, $\chi^{2}(10)=1.799$, p-value- 0.41

\begin{tabular}{|c|c|c|c|c|c|}
\hline $\boldsymbol{\pi}$ & $\boldsymbol{Y}$ & $\boldsymbol{I}$ & $\boldsymbol{M}$ & Sm & $\boldsymbol{L r}$ \\
\hline $\begin{array}{l}\mathbf{0 . 3 3} \\
(\mathbf{0 . 0 4})\end{array}$ & $\begin{array}{l}-7.09 \\
(0.14)\end{array}$ & $\begin{array}{l}0.43 \\
(0.05)\end{array}$ & 1 & 0 & 0 \\
\hline $\mathbf{0}$ & 1 & 0 & 0 & 1 & 0 \\
\hline $\mathbf{0}$ & $\mathrm{o}$ & 1 & 0 & 0 & 1 \\
\hline
\end{tabular}

The restricted core/main model is robustly accepted and these results are consistent with the economic and econometric theory. The first co-integrating relation consists on money market 


\section{Review of Economics and Development Studies, Vol. 6 (3) 2020, 575-589}

equilibrium, second relates real economic activity with a stock market, and the third relates to an "approximation of the pure expectations hypothesis" based on the arbitrage relation between short term and long term bonds. In this regard we applied Johansen cointegration method for the estimated coefficients of first two equations but for arbitrage equations we present OLS because both variables are integrated of order zero and OLS can provide robust results.

Table 5: Estimated Model for Long Run

\begin{tabular}{|l|l|l|l|}
\hline $\begin{array}{l}\text { Dependent } \\
\text { Variable }\end{array}$ & $\boldsymbol{M}$ & $\boldsymbol{s m}$ & $\boldsymbol{L r}$ \\
\hline Intercept & $9.3(1.41)$ & $-1.34(1.70)$ & $2.18(0.35)$ \\
\hline $\boldsymbol{Y}$ & $1.78(0.28)$ & $1.87(0.39)$ & - \\
\hline $\boldsymbol{S m}$ & - & - & - \\
\hline $\boldsymbol{I}$ & $0.021(0.02)$ & - & $0.78(032)$ \\
\hline $\boldsymbol{\Pi}$ & $-0.056(0.03)$ & - & $\mathrm{R}^{2}=0.87$ \\
\hline $\begin{array}{l}\text { Note: (i) Standard errors in parentheses (ii) *Indicates statistically } \\
\text { significant at 5\% whereas ** indicates at 10\% }\end{array}$ \\
\hline
\end{tabular}

There exists a positive and significant relation between stock market and industrial production. The output elasticity of stock market is greater than one i.e., one percentage point rise in industrial production brings 1.87 percentage point rise in the stock market. This is however, concluded that forecasting stock market returns is quite heavily dependent on changes that occur in manufacturing production, the best indicator for predicting the country's economic environment. In a nutshell, industrial production is directly proportional to the stock price (Nishat, and Shaheen 2004). The similar relationship was found by Lee (1992), Chen et al (1986), Fama (1990) and Geske and Roll (1983) in U.S.A., and by Darratt (1990) in Canada. The results of this equation indicates the practice of Pakistan Stock Market, i.e., many large scale industry hold the share in stock volume and the industrial health of the economy increases the stock market performance showing increase of predictability and trust of the rational economic agent.

Table 5 also verifies the assumptions of the model. The sign of output money relationship is positive indicating that the output elasticity of money is greater than one. The coefficient of interest rate show that short term T-bill rate does not affect money supply, statistically. This indicates zero interest elasticity of money supply thus indicating a vertical money supply curve. The relationship between money supply and inflation is according to theory and the low magnitude indicates low responsiveness of central bank towards inflationary expectations through money supply. 2 This indicates absence of any rule for the inflationary dynamics. However, the more weight is given to the output.

The given results depict that long term financial asset prices are positively and significantly explained by short term rate. That is the short term elasticity of call money rate is negative which means that a 1 percentage point increase in short term money market rate will bring about 0.83 percentage point decrease in long term rate. The first group of hypotheses consists of a quantitative term of perception that the long rate responds too much to the contemporaneous short rate. This hypothesis of excess-sensitivity is suggested by unpredictability of long-term rate of interest. According to Shiller (1992) “...in this smoothing property of the expectations hypothesis the long rates are too volatile to be consistent with the theory." 
Review of Economics and Development Studies, Vol. 6 (3) 2020, 575-589

\subsection{Shocks' Analysis}

In econometrics the impulse response is to be defined as the response of the system as a result of the external shocks. We used restricted VAR model to obtain the IRFs of all the variables of the model.

\subsection{Impulse responses to an inflation shock}

The response of output to inflation shock is negative (as in Balnchard \& Quah, 1989) and diverges from the equilibrium point to a minimum of $0.1 \%$ in $18^{\text {th }}$ quarter. After that outputs starts converging but remain negative. It can be explained with inflation shock. The rise in price level provide an opportunity to produce more to the manufacturers while decreases demand which in long run lead to reduction in output due to excess in supply.
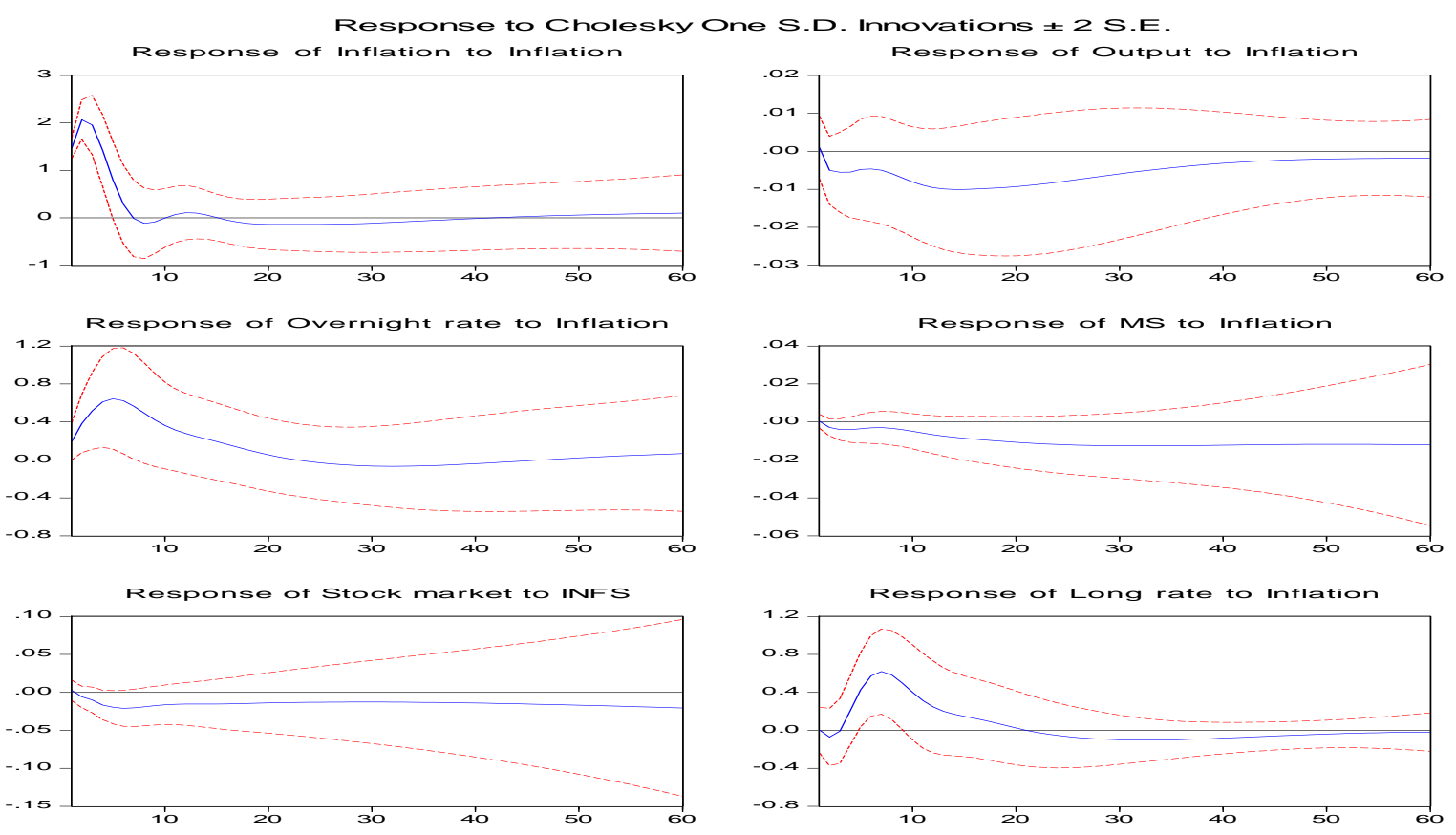

FIGURE 1: IMPULSE RESPONSE TO AN INFLATION SHOCK

The effect of inflation on interest rate can be explained through so-called Mundell effect that is an unexpected increase in inflation decreases real wealth, increasing savings; causing a fall in real interest rate to regain goods market equilibrium. Both long and short term interest rate diverge in the initial twenty quarters. On the other hand, the stock market is initially depressed from zero initial response or by a shock to inflation rate; however it starts converging after 10 quarters but ultimately remained negative. According to the monetarists, monetary authorities exogenously set the long run money growth and inflation rate. With a positive inflation shock the money supply reduces and will diverge and remain negative.

\subsection{Impulse response to money supply shock}

As money supply increases price increases proportionally. The output level in Pakistan rises with a positive shock of money supply. According to monetarist, any sudden increase in the money supply usually causes output level to upsurge above its natural level but in only long run it causes proportional increase in the inflation. It is specified by the Keynesians that "any change in liquidity will directly influence stock prices if and only if the changes in the it develop probability regarding future monetary stance." 

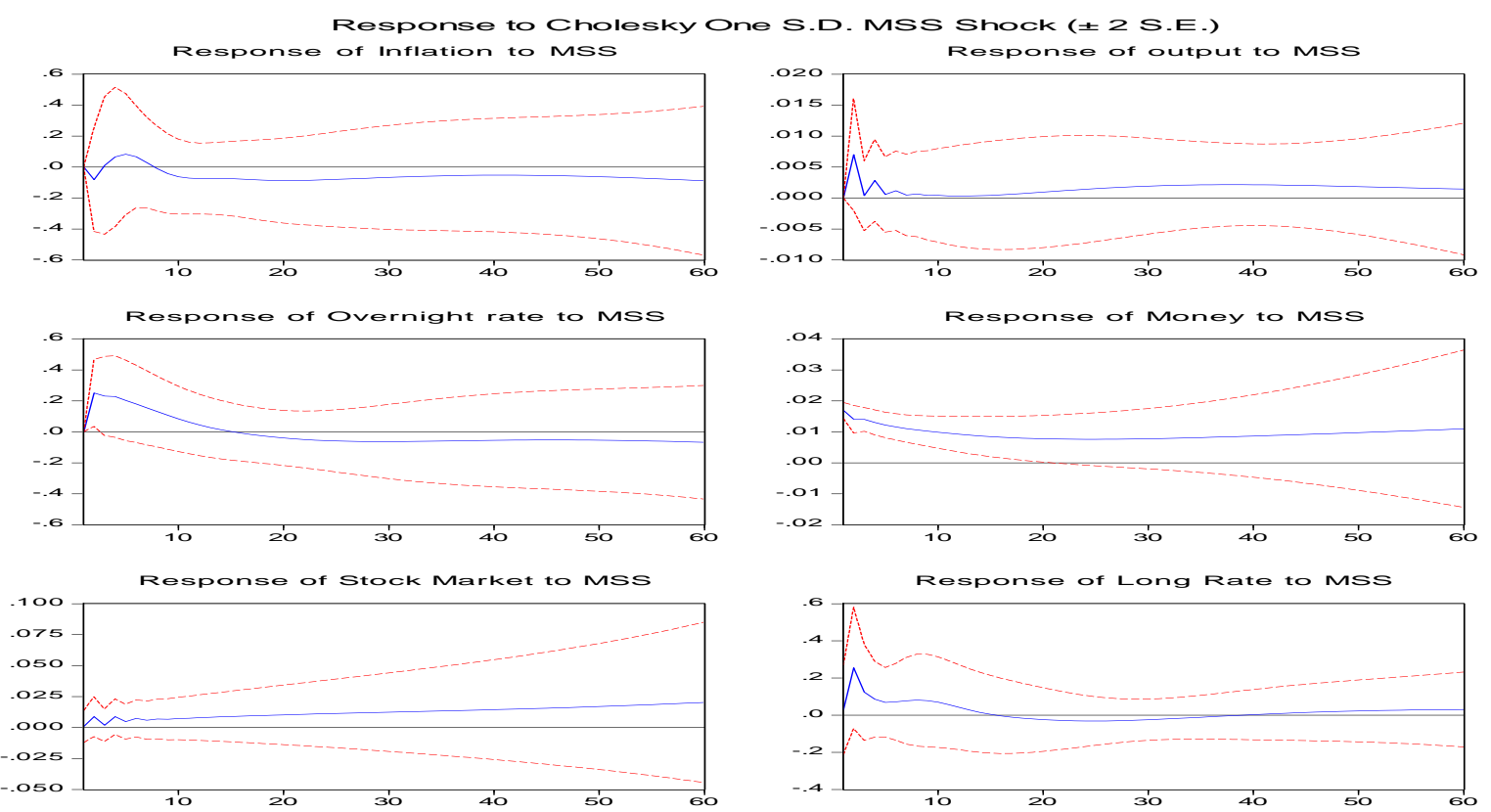

\section{FIGURE 2 IMPULSE RESPONSES TO MONEY SUPPLY SHOCK}

So a positive money supply shock faced by the economy will usher the economic agents to foresee the tightening monetary policy in near future. They ask for more funds in prediction of tight policy stance in near future and resultantly will push the existing rate of interest upwards. The money supply shock makes long term rate to diverge. After third quarter long term rate starts converging.

\subsection{Impulse response to output shock}

A positive shock to aggregate supply generally has negative outcome in the form of money inflation. An increase in money generates real benefits for those economic agents who receive this additional portion of liquidity instantaneously. During this period prices do not adjust (in short run). These private benefits to economic agents, however, are drawn at the cost of the benefits of other members of that economy, who with their initial money holding lost purchasing power with less quantity of goods availability at the same time. In the next period (dynamically) the output becomes less efficient. Thus the the economic agents who are responsible for growth generation process are left with relatively fewer resources than they would have had otherwise.
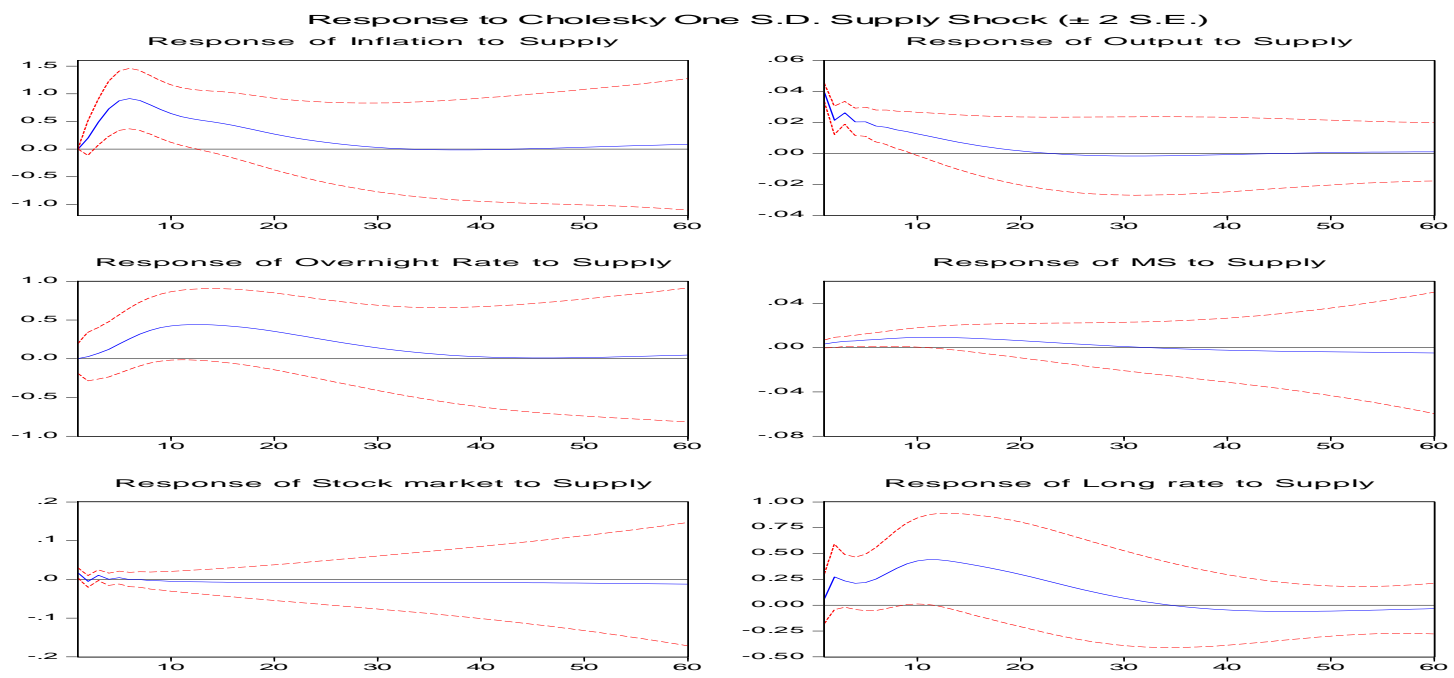

FIGURE 3: IMPULSE RESPONSE TO SUPPLY SHOCK 
The typical supply shock increases the production capacity of the economy that diverges to in first quarter. But later in the next quarter it starts converging and remains same from twenty second to onward quarters. With supply shock, short term interest rate raises to a maximum of in tenth quarter and afterwards interest rate starts converging. The central bank accommodates the shock by decreasing interest rate to eliminate 'excess supply' of the goods in market and bring inflation back to target. Money supply response to supply shocks is minimal because of its weak relationship. Likewise stock market leads output and overshoots rather. Long term rate is higher in the short run because of accommodating role of central bank. It reaches to a maximum in $12^{\text {th }}$ quarter but from the very next quarter it starts converging.

\subsection{Impulse response to short run rate shock}

Simply, a shock in interest rates implies that consumers and firms have to pay more to finance consumption and other projects.3 A shock to short-term interest rate leads to lower inflation, i.e., the cost of borrowing rises, which reduces the level of investment and in turn reduces output and let it diverge from equilibrium. But in the long run output start converging. Money and stock markets show minimal response to interest rate. The response of one point increase in long rate changes the perception about future interest rate and lead "short-term interest rate" to rise.
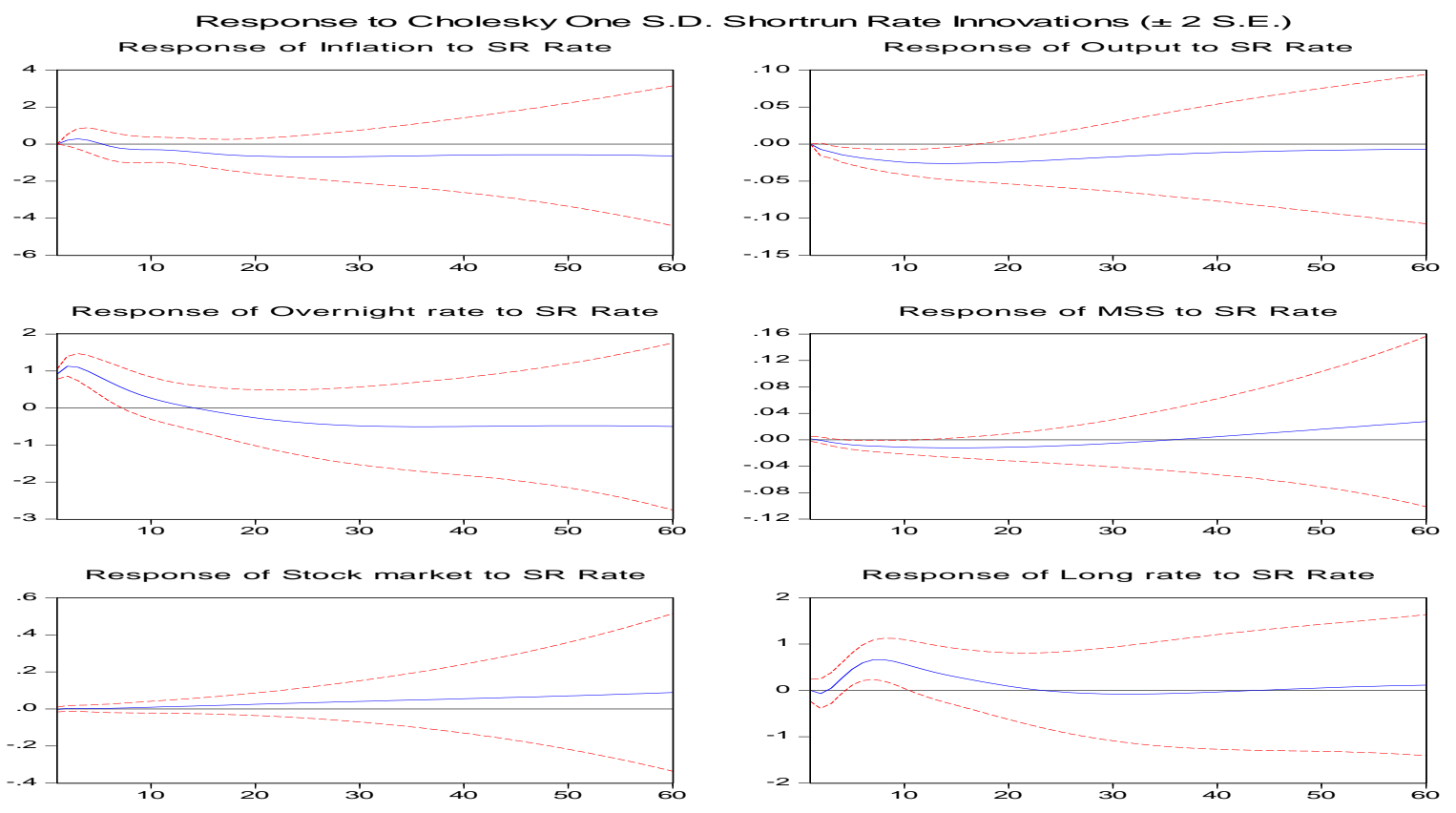

\section{Figure 4: IMPULSE RESPONSE TO SHORT RUN RATE SHOCK}

\subsection{Impulse response to long run rate shock}

Long-term interest rates are determined by market. Here a shock to long rate is connected with higher inflation which starts diverging back to equilibrium point. The short run interest rate is initially depressed by a shock to long term rate and converges after eighteenth quarter. Stock market get minimal explained by a shock to long run interest rate, overall its response is converging. Same is the response of money supply. The output level is initially depressing by a shock to long term rate,

3 Numerous households buy long-lasting goods such as cars on credit. Higher payments deject the consumers in trading these goods and hence, reduce their consumption. In same manner, for the investments that can happen to the firms for their financial needs. At the time of increase in interest rates, investments drop down, since it becomes more costly to make use of money and more attractive to do saving. Thus, consumption decreases, that leads to a reduced demand. This keeps prices of the commodities down and inflation decreases. 
however, it converge in thirtieth quarter.
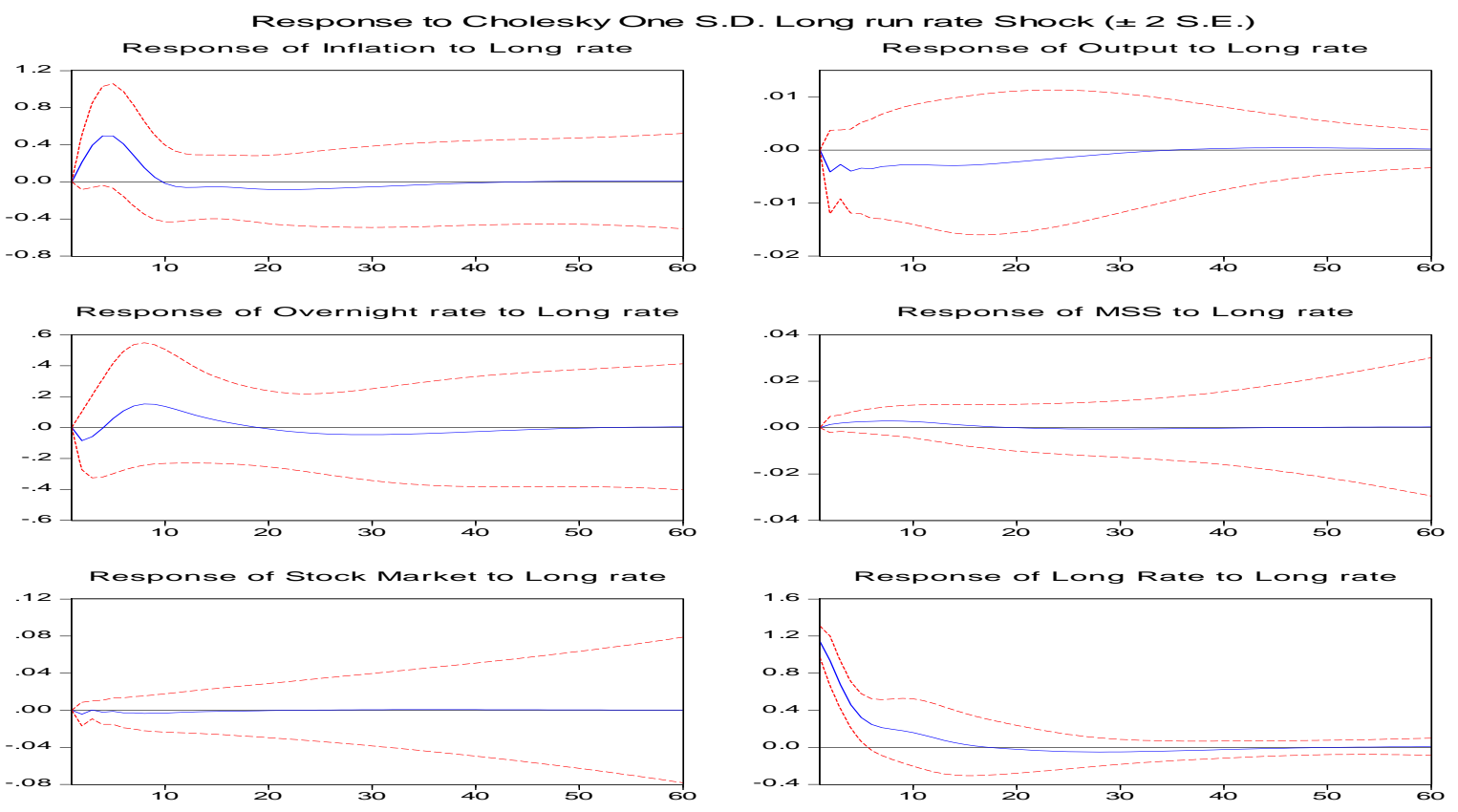

FigURE 5: IMPULSE RESPONSE TO LONG TERM INTEREST RATE SHOCK

\section{Conclusions and Policy Implications}

The role of the stock market in the economy is to raise its capital and also to ensure that the funds mobilized are utilized in the most profitable opportunities. This study performed the basic analysis of linkages between asset markets (used stock market as proxy) and monetary policy process to answer whether changes in the identified macroeconomic variables affect stock market of Pakistan. Our analysis has been based on univariate and multivariate analysis. The novel feature of the study is to test the restrictions of cointegration vectors, which help to find out the sequence of macroeconomic and policy variables in a model. To determine the money market equilibrium, interaction between real economy and asset market equilibrium and arbitrage between long and short term rates in the Pakistan economy for the period 1991Q3 to 2015Q2 is tested.

The results indicate that positive long-run relation between the stock market and real output allows the identification of a demand shock as the shock permanently affecting the stock market. Similarly money supply shock and short term rate shock permanently affect stock market while inflation shock has negative long run impact on stock market. The results also indicate that the money supply reaction function is less responsive to inflation and the policy maker put more weight to output.

Our results imply that due to cost-push nature of inflation policy maker has some flexibility to target other sectors of the economy, e.g., investments in the asset markets. Our results also imply the SBP can use interest rate smoothing approach by targeting long run interest rate through arbitrage conditions. Since our results indicate that the stock/other financial markets and money markets are inter-related, the institutional collaboration between the Security and Exchange Commission (SEC) and the central bank is significant. Their policies should be in line with the quality analyses of the markets.

To incorporate international dynamics, this analysis can be further extended by including exchange rate and the macroeconomic indicators of anyone of the major trading partners. 


\section{Review of Economics and Development Studies, Vol. 6 (3) 2020, 575-589}

\section{REFERENCES}

Ahmed, A. E. M., \& Suliman, S. Z. (2011). The long-run relationship between money supply, real GDP, and price level: Empirical evidence from Sudan. Journal of Business Studies Quarterly, 2(2), 68.

Ahmed, Shamim, and M. Golam Mortaza. Inflation and economic growth in Bangladesh: 1981-2005. No. id: 3033. 2010.

Angelopoulou, E., Balfoussia, H., \& Gibson, H. D. (2014). Building a financial conditions index for the euro area and selected euro area countries: what does it tell us about the crisis?. Economic Modelling, 38, 392-403.

Ayyoub, M., Chaudhry, I. S., \& Farooq, F. (2011). Does Inflation Affect Economic Growth? The case of Pakistan. Pakistan Journal of Social Sciences (PJSS), 31(1).

Baumol, W. J. (1965). The stock market and economic efficiency (No. 6). Fordham Univ Pr.

Bayo, F. (2011). Determinants of inflation in Nigeria: An empirical analysis. International Journal of Humanities and social science, 1(18), 262-271.

Blanchard, O. J. (1981). Output, the stock market, and interest rates. American Economic Review, 71(1), 132-143.

Blanchard, O. Q., \& Quah, D. (1989). The dynamic Effects of aggregate Supply and Demand Disturbances. American Economic Review, 793.

Brave, S. A., \& Butters, R. (2011). Monitoring financial stability: A financial conditions index approach. Economic Perspectives, 35(1), 22.

Chaudhry, I. S., Qamber, Y., \& Farooq, F. (2012). Monetary policy, inflation and economic growth in Pakistan: Exploring the co-integration and causality relationships. Pakistan Journal of Commerce and Social Sciences (PJCSS), 6(2), 332-347.

Chen, N. F., Roll, R., \& Ross, S. A. (1986). Economic forces and the stock market. Journal of business, 383-403.

Comincioli, B. (1996). The stock market as a leading indicator: An application of granger causality. University avenue undergraduate journal of economics, 1(1), 1.

Darrat, A. F., \& Mukherjee, T. K. (1986). The behavior of the stock market in a developing economy. Economics Letters, 22(2-3), 273-278.

Doguwa, S. I. (2012). Inflation and economic growth in Nigeria: Detecting the threshold level. CBN journal of Applied Statistics, 3(2), 99-124.

Dynan, K. E., Elmendorf, D. W., \& Sichel, D. E. (2006). Can financial innovation help to explain the reduced volatility of economic activity?. Journal of monetary Economics, 53(1), 123-150.

Eichenbaum, M. (1997). Some thoughts on practical stabilization policy. The American Economic Review, 87(2), 236-239.

Espinoza, R., Fornari, F., \& Lombardi, M. J. (2012). The role of financial variables in predicting economic activity. Journal of Forecasting, 31(1), 15-46.

Fama, E. F. (1981). Stock returns, real activity, inflation, and money. The American economic review, 71(4), 545-565.

Gauthier, C., \& Li, F. (2005). Linking real activity and financial markets: the first steps towards a small estimated model for Canada. Press \& Communications CH-4002 Basel, Switzerland E-mail: publications@ bis.org Fax:+ 41612809100 and+ 41612808100 This publication is available on the BIS website (www. bis. org)., 253.

Gauthier, C., Graham, C., \& Liu, Y. (2003). Financial Conditions Indices for Canada. Bank of Canada.

Geske, R., \& Roll, R. (1983). The fiscal and monetary linkage between stock returns and inflation. The journal of Finance, 38(1), 1-33.

Guichard, S., Haugh, D., \& Turner, D. (2009). Quantifying the effect of financial conditions in the euro area, Japan, United Kingdom and United States.

Hernando, I., \& Martínez-Carrascal, C. (2008). The impact of financial variables on firms' real 


\section{Review of Economics and Development Studies, Vol. 6 (3) 2020, 575-589}

decisions: evidence from Spanish firm-level data. Journal of Macroeconomics, 30(1), 543-561.

Humpe, A., \& Macmillan, P. (2009). Can macroeconomic variables explain long-term stock market movements? A comparison of the US and Japan. Applied Financial Economics, 19(2), 111-119.

Johansen, S. (1988). Statistical analysis of cointegration vectors. Journal of economic dynamics and control, 12(2-3), 231-254.

King, R., Plosser, C. I., Stock, J. H., \& Watson, M. W. (1987). Stochastic trends and economic fluctuations.

Lee, B. S. (1992). Causal relations among stock returns, interest rates, real activity, and inflation. The Journal of Finance, 47(4), 1591-1603.

Liu, M. H., \& Shrestha, K. M. (2008). Analysis of the long-term relationship between macro-economic variables and the Chinese stock market using heteroscedastic cointegration. Managerial Finance, 34(11), 744-755.

Mahmood, M. T., \& Shahab, S. (2012). Effects of Optimal Monetary Policy Rules on Welfare in a Small Open Economy: A Simulation Analysis. International Journal of Business and Social Science, 3(22).

Malik, W. S., \& Ahmed, A. M. (2010). Taylor rule and the macroeconomic performance in Pakistan. The Pakistan Development Review, 37-56.

Mubarik, Y. A., \& Riazuddin, R. (2005). Inflation and growth: An estimate of the threshold level of inflation in Pakistan. Karachi: State Bank of Pakistan.

Nishat, M., Shaheen, R., \& Hijazi, S. T. (2004). Macroeconomic Factors and the Pakistani Equity Market [with Comments]. The Pakistan Development Review, 619-637.

Puah, C. H., \& Jayaraman, T. K. (2007). Macroeconomic activities and stock prices in a South Pacific Island economy. International Journal of Economics and Management, 1(2), 229-244.

Ratanapakorn, O., \& Sharma, S. C. (2007). Dynamic analysis between the US stock returns and the macroeconomic variables. Applied Financial Economics, 17(5), 369-377.

Shiller, R. J. (1992). Market volatility. MIT press.

Soejima, Y. (1996). The long-run relationship between real GDP, money supply and price level: unit root and cointegration tests with structural changes. Monetary and Economic Studies, 14(2), 23-52.

Sohail, N., \& Hussain, Z. (2009). Long-Run and Short-Run Relationship between Macroeconomic Variables and Stock Prices in Pakistan. Pakistan Economic and Social Review, 47(2), 183-198. 